\title{
Preliminary descriptions of some new, australian Gryllids and Forficulids
}

\author{
by
}

\section{Eric Mjöberg.}

During my scientific, biological expedition to Australia I9IO-I91 I, I brought together a collection of about 20,000 insects. These are still waiting for their determination, only some few groups having yet been worked out. The material comes mainly from the western parts of the australian continent. When now starting my second australian expedition, this time to the eastern parts, I hope to enlarge the entomological material considerably. After my return, probably in the end of next year, I intend to publish the whole entomological result in the same volume (Kungl. Vetenskapsakademiens Handlingar).

Here I give only some short preliminary descriptions of the species of the groups, already worked, out by me.

\section{Dermaptera.}

\section{Pygidicrana ambigua n. sp.}

Elongated; head triangular, yellow, with a dark stripe in the middle of the front, coalescing anteriorly with a transversal, dark band; hindhead with two dark, parallel stripes; on each side behind the eyes a black line. Antennæ 30 jointed, yellow. Prothorax with two darkbrown forwards di- 
verging nearly parallel stripes; squamæ yellow, on the lateral margin darkbrown. Legs yellow; forceps in both sexes nearly of the same shape, densely covered with long yellow, hairs.

Long. of $18 \mathrm{~mm}$., 요 $19 \mathrm{~mm}$.

Allied to Pyg. dameli DoHrN, but differing by the colour, the entirely yellow antennæ, the yellow and dark abdominal segments, the smaller size etc.

5 specimens collected at Noonkanbah and Broome, WestKimberley N. W. Australia. The species lives under bark.

\section{Labidura leucotarsata n. sp.}

Allied to Lab. riparia PALL. and Lab. bengalensis DoHRN but apparently distinct from both.

Head broader than prothorax, reddish brown; mouthparts and clypeus lighter. Elytra dark with reddish suture, femora dark-brown, at the base lighter, tibiæ yellow, tarsi nearly white. Forceps with long branches, only slightly curved, behind the middle with a distinct tooth, and at the top with another distinct one.

Long. \& $26 \mathrm{~mm}$.

Differing from Lab. riparia PALL. by having two distinct teeth on the forceps, from Lab. hengalensis DOIIRN by the teeth being placed in a different way, the much smaller size etc.

A single $\delta$ from Perth, S. W. Australia.

\section{Labidura australica n. sp.}

Body long and elongated, covered by fine soft hairs; antennæ totally dark. Prothorax with yellow board, impressed in the middle. Elytra very long; squamæ long and distinct at the top with a yellow spot. Forceps with the branches slightly curved, behind the middle with a little tooth.

Long. ठैं $12 \mathrm{~mm}$.

Allied to Lab. vicina $\mathrm{LUC}$, but differing by the darker 
colour, the black femora, the much longer elytra, the forceps etc. A single $\delta$ from West-Kimberley. N. W. Australia.

\section{Anisolabis pilosiventris n. sp.}

Elongated, black, a little brilliant. Head black, mouthparts and clypeus dirty yellow, the hind angles broadly rounded. Antennæ dark, with fine hairs, the second joint and some of the joints 8-I I light yellow. Prothorax a little broader posteriorly with narrow, yellow margin. Sternum totally whitish yellow. Femora and tibiæ with broad, dark rings. In the $\delta^{\lambda}$ the last ventral segment long and densely covered with yellow hairs. Forceps in the of without teeth, strongly curved.

Long. of $14 \mathrm{~mm}$., $+\mathrm{I} 6 \mathrm{~mm}$.

$2 \delta \hat{\delta}$ found at Perth and Mundaring, I $q$ at Perth.

\section{Spongiphora australiana n. sp.}

Body dark, a little brilliant, antennæ I5-jointed, dark brown, only some of the basal joints a little lighter; eyes with big facetts. Prothorax a little broader posteriorly, with yellow margin, impressed in the middle, anterior angles a little obtuse, hind angles rounded. Elytra very finely punctured, squama distinct, long at the top with a yellow spot; legs white-yellow, femora and tibiæ with broad, dark rings. Anal segment in $\delta$ rectangular, hind angles nearly right; forceps in $\delta$ near the base with one very sharp, at the top with one tooth, in $q$ unarmed.

Long, \& $9 \mathrm{~mm}$., o $8,5 \mathrm{~mm}$.

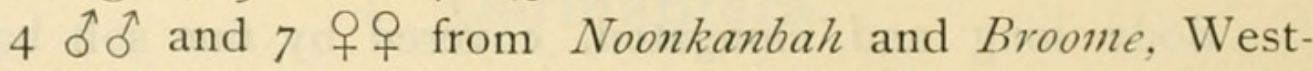
Kimberley (dec.-april).

\section{Chætospania australis n. sp.}

No representative of this genus was previously known from Australia. -

Body strongly depressed, castaneous brown, head and 
elytra brilliant black; head broader than long, in the middle with some indistinct impressions; mouth-parts and clypeus reddish brown; antennæ $\mathrm{I} 2$-jointed, long and densely hairy; prothorax with a fine line in the middle and a distinct impression on each side; the front and hind angles rounded. Elytra very brilliant, densely and finely punctured; abdominal segments with long, erect, yellow hairs. Forceps at the base straight and here with a sharp tooth, then bent and provided with a tooth, at the top bent again.

\section{Long. $\widehat{0}$ II $-\mathrm{I} 2 \mathrm{~mm}$., + IO $\mathrm{mm}$.}

Of this very characteristic species, I have found $6 \delta \delta$ and II $q+q$ under bark in the rain-forests on the top of Blackal Range, S. Queensland.

\section{Chelisoches kimberleyensis n. sp.}

Body elongated, depressed, without hairs; head flat, mouth-parts and clypeus reddish brown, brilliant black, narrowing backwards; antennæ black, 24-jointed. Prothorax posteriorly a little broader, front angles obtuse, hind angles rounded; elytra long, as the squamæ testaceous, at the hind margin very finely striated. Legs short, black, only the tarsal joints and the top of the tibiæ red-yellow; all abdominal segments with a transversal row of fine tubercles and with rugulous sculpture. Forceps in $\delta$ long, slightly bent, at the base with a very big tooth, behind the middle a smaller, obtuse tooth.

Long. of $22 \mathrm{~mm}$., f $24 \mathrm{~mm}$.

Apparently allied to Ch. morio $F$. and Ch. australicus Guill., but differing from the former by the red colour on the elytra, the forceps etc., from the later by the tarsal joints and also the forceps, antennæ etc. I have only two specimens of this characteristic species, I $\delta$ from St. George Range, West-Kimberley, taken under Pandanusbark, and I $q$ taken by Mr. Giles, Perth, near Drysdale River, also in Kimberley. - 


\section{Gryllodea.}

The collection contains about I6 new species and several new genera; only 8 new species and I new genus are described here.

\section{Fam. Gryllotalpidæ.}

\section{Austrotalpa n. g.}

Allied to the genus Gryllotalpa but differing by following characters.

The body not finely hairy, but naked and brilliant. Elytra in $q$ very long, covering very nearly the whole hindbody, provided with very strong parallel nerves, in $\delta$ much shorter. The endspurs of the hind tibiæ regular and placed in the same line.

\section{Austrotalpa pluvialis n. sp.}

The body broad, brilliant, only the hind-head finely hairy; mouth-parts dark-brown, only the labrum reddish yellow. Prothorax strongly brilliant, in the middle with a lighter stripe, very finely punctured. Elytra in $\delta^{2}$ very short, with very strong nerves; vena mediastina with about ten branches, the alæ very much reduced in size; elytra in $f$ only near the base with some few triangular areas. The hind body a little brilliant, but provided with very fine short yellow hairs; the last ventral segment of peculiar shape, in the middle impressed, the lateral margin of this impression provided with long yellow hairs. Cerci of normal size, thick and short, with fine and short, and also some longer hairs. Long. ơ $33 \mathrm{~mm}$., ㅇ $3 \mathrm{I} \mathrm{mm}$.

I have captured only two specimens, I $\delta$ and $I \quad q$ in the rain-forests on the top of Blackal Range, S. Queensland.

No doubt the shortly described species, Gr. nitidula SERV., known only in the female sex, will also have to be placed in this new genus. 


\section{Tridactylus australicus n. sp.}

Body elongated, head dark yellow; on the inside of the eyes a yellow mark. Prothorax much broader than the head, the margins yellow; antennæ short and thick, the first seven joints of the same length, the 8:the a little longer, the 9:th still longer, the last joint the longest, all joints with short and thickly set hairs. Legs light yellow, the two hind pairs brownspotted; the hind tibiæ with two small obtuse teeth over the lamellæ; the inferior spurs twice as long as the lamellæ, the upper spurs more or less hyalin, straight. Metatarsus longer than the upper spurs but shorter than the inferior, densely clothed with short hairs. Elytra more or less reduced, with a lighter transversal band, dark brown, alæ well developed, the front board brown with small white spots. Cerci with long hairs.

Long. $5 \mathrm{~mm}$.

Of this species I have collected 8 specimens in WestKimberley near water.

\section{Fam. Gryllidæ.}

\section{Nemobius australianus n. sp.}

Body of moderate size, dark. Head and prothorax with long, black, erect hairs, front brilliant black, a halfmoonshaped line over the root of the antennæ yellow, hind head with four lighter median stripes. Prothorax rounded on the sides, dark, with a distinct middle line. Elytra strongly reduced, covering only half the hind body; between the parallel, longitudinal nerves some transversal ones. Legs dark, the two first pairs with yellow rings; cerci short, much shorter than the hind tibiæ; the ovipositor long, of the same length as the hind tibiæ.

Long. of $8 \mathrm{~mm}$.

Allied to $N$. fasciatus DE GEER, but apparently distinct. 
Belongs to the group silvestris - annulipes - australis, with strongly reduced elytra and a long ovipositor.

A single $q$ from Perth, S. W. Australia.

\section{Nemobius biguttatus n. sp.}

Dark brown; head black with prominent eyes and long hairs, clypeus and palpi pale yellow; prothorax black, a little brilliant, with distinct middle-line. Elytra covering the hind body, dark, the whole campus lateralis nearly white; the longitudinal nerves strong; alæ very long, much longer than the hind body; the two first pairs of legs dirty yellow with small darker spots; hind legs dark with a little round, white spot. The ovipositor short and bent, cerci much longer, dark brown, with long and short hairs.

Long. $q 5 \mathrm{~mm}$.

Two $q$ f from Noonkanbah, West-Kimberley, N. W. Australia.

\section{Gryllus kimberleyensis n. sp.}

Head brilliant, with one ocellar spot, one transversal stripe between the eyes, and six more or less distinct, yellow longitudinal stripes on the hind head; prothorax flat, black, with some yellow spots near the hind angles. Elytra in $\delta$ short and broad, as a rule covering the hind body, campus lateralis whitish, venæ obliquæ 2, not strongly developed, slightly curved; speculum of caracteristic shape, nearly rectangular, not divided by any transversal nerve; chorda prima giving off one nerve to the speculum. Vena mediastina with two branches; in $f$ the alæ well developed, the ovipositor of the length of the hind femora.

Long. $0 \mathrm{I} 5$, $+16 \mathrm{~mm}$.

A little allied to Gr. brunneri W.; the $q$ has the same characteristic nervature, but well developed hind wings and the $\delta$ only two venæ obliquæ.

$2 \delta \widehat{\delta}$ and 2 $q$ from Noonkanbah and Derby in WestKimberley, N. W. Australia. 


\section{Gryllodes curtipennis n. sp.}

Body depressed, dark brown, with short and fine gray hairs; head dark castaneous brilliant, mouth-parts, ocelli and partly the genæ yellow. Legs, coxæ, sternum and the middle of the hind body yellow. Elytra in short, only covering half the hind body, venæ obliquæ 2 ; speculum rhomboidal, divided by a transversal nerve and receiving a branch from chorda prima; in $f$ the elytra short, the campus lateralis with 5-6 parallel nerves; alæ well developed; legs, sternum and the middle of the ventral segment yellow; cerci in $\delta \vec{a}$ little longer, in $q$ a little shorter than the hind femora.

Long. of $17 \mathrm{~mm}$., $q \mathrm{I} 7 \mathrm{~mm}$.

$2 \delta \hat{\delta}$ and 3 우 from Noonkanbah and Derby in WestKimberley, N. W. Australia.

\section{Gryllodes fulviceps n. sp.}

Head reddish yellow, brilliant but covered by very fine short hairs. Prothorax anteriorly broad, reddish yellow, posteriorly darker. Elytra short, not covering the whole hind body, campus lateralis whitish, with 5 parallel nerves; between vena mediastina and the 5 th nerve of campus lateralis a row of darker spots; campus dorsalis divided into numerous small areas. Alæ well developed, much longer than the hind body. Cerci very long, at least not shorter than the hind femora, provided with very long fine hairs.

Long. o $16 \mathrm{~mm}$.

5 우 from Noonkanbah, West-Kimberley, N. W. Australia.

\section{Gryllodes mediocris n. sp.}

Head black, six small short stripes on the hind head, the ocelli, a median longitudinal stripe on clypeus and the cavities of the antennæ reddish yellow; hind-head distinctly gray-haired, prothorax a little flattened, as broad as the head, flat, grayhaired, at the front and hind margin with very long black hairs; elytra not entirely covering the hind body,

Entomol. Tidskr. Arg. 34. H. I (19I3). 
speculum trapezoidal, finely striated, receiving a little branch from chorda prima, venæ obliqua 2, very litte curved. Alæ well developed, with two dark, radial stripes.

Long. ơ $\mathrm{I} 2 \mathrm{~mm}$., $q$ I I $\mathrm{mm}$.

5 specimens, I $\hat{\delta}$ and $4 q+$, from Noonkanbah, WestKimberley, N. W. Australia. 


\section{$2 \mathrm{BHL}$ Biodiversity Heritage Library}

Mjöberg, E. 1913. "Preliminary descriptions of some new Australian Gryllids and Forficulids." Entomologisk tidskrift 34, 26-34. https://doi.org/10.5962/bhl.part.1632.

View This Item Online: https://www.biodiversitylibrary.org/item/42378

DOI: https://doi.org/10.5962/bhl.part.1632

Permalink: https://www.biodiversitylibrary.org/partpdf/1632

\section{Holding Institution}

Smithsonian Libraries

\section{Sponsored by}

Smithsonian

\section{Copyright \& Reuse}

Copyright Status: NOT_IN_COPYRIGHT

This document was created from content at the Biodiversity Heritage Library, the world's largest open access digital library for biodiversity literature and archives. Visit BHL at https://www.biodiversitylibrary.org. 